Lisbon - Malacca Port Cities Twin Conferences 2019 / 2020

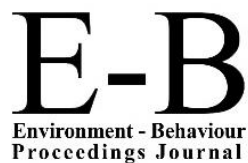

AicQoL2020Malacca

ASLI (Annual Serial Landmark International) Conferences on QoL2020

https://www.amerabra.org; https://sspu.uitm.edu.my/cebs; https://www.emasemasresources.com/

8th AMER International Conference on Quality of Life

Mahkota Hotel Melaka, Malacca, Malaysia, 18-19 Mar 2020

(Due to the Covid-19 lockdown, paper virtually presented on 25 Mar 2020)

\title{
Accessibility Adaptation in the Design of Heritage Boutique Hotels: Malacca case studies
}

\author{
Syazwani Abdul Kadir¹, Mariam Jamaludin², Abd Rahim Awang ${ }^{3}$ \\ 1,3 Centre of Studies for Interior Architecture \\ 2 Centre of Studies for Architecture \\ Faculty of Architecture, Planning and Surveying \\ Universiti Teknologi MARA (UiTM), Puncak Alam, Malaysia \\ syazwani179@uitm.edu.my, marja67@gmail.com, abdrahimawang@yahoo.com \\ Tel: +603-5544 4385
}

\begin{abstract}
This paper undertakes a study on accessibility adaptation in the design of heritage boutique hotels in Malacca. Three heritage boutique hotels located in Malacca City were selected as the case studies. The objective is to explore the heritage boutique hotels' methods of adapting accessibility in their hotel design. Research methodology employed is observation, which include site observation and photo documentation. Data from the observation were analyzed and discussed qualitatively. Findings indicate that all three case studies were designed with users' accessibility in mind in spite of the challenge in carefully preserving the buildings' heritage value.
\end{abstract}

Keywords: Accessibility adaptation; Heritage building; Hotel design; Boutique hotel

eISSN: 2398-4287 @ 2020. The Authors. Published for AMER ABRA cE-Bs by e-International Publishing House, Ltd., UK. This is an open access article under the CC BYNC-ND license (http://creativecommons.org/licenses/by-nc-nd/4.0/). Peer-review under responsibility of AMER (Association of Malaysian Environment-Behaviour Researchers), ABRA (Association of Behavioural Researchers on Asians) and cE-Bs (Centre for Environment-Behaviour Studies), Faculty of Architecture, Planning \& Surveying, Universiti Teknologi MARA, Malaysia.

DOI: https://doi.org/10.21834/e-bpj.v5i13.2094

1.0 Introduction

With the theme of "Anchoring Growth of People," the Eleventh Malaysia Plan listed "Enhancing inclusiveness towards an equitable society" and "Improving wellbeing for all" in the six strategic thrusts to address the citizens' needs towards a progressive Malaysia's development (National Institute of Public Administration, 2015). Therefore, accessibility can be considered as an essential aspect in Malaysia's socio-economic plan to enhance the wellbeing of Malaysian citizens. Many studies on accessibility have been conducted for the improvement of the built environment in Malaysia; however, studies that are scoped into accessibility at historical tourist attractions are still deficient. Some precedent accessibility studies have highlighted the need to foster more accessible tourism, especially at the place of tourists' attractions such as historical sites, monuments, and heritage buildings (Abdul Kadir, Jamaludin \& Awang, 2019; Jamaludin \& Abdul Kadir, 2012; Kose, 2015). This indicates that the common issue between accessibility and heritage seems to be the lack of accessibility provisions in the restored built heritage environment.

Pertaining to the said concern, this research aims to discover the accessibility adaptation in the design of selected heritage boutique hotels located in Malacca City centre. The objective of the study is to explore the heritage boutique hotels' methods of adapting accessibility in their hotel design. This research hopes to accumulate the hotels' attentive ways in adapting accessible facilities at their

eISSN: 2398-4287 @ 2020. The Authors. Published for AMER ABRA cE-Bs by e-International Publishing House, Ltd., UK. This is an open access article under the CC BYNC-ND license (http://creativecommons.org/licenses/by-nc-nd/4.0/). Peer-review under responsibility of AMER (Association of Malaysian Environment-Behaviour Researchers), ABRA (Association of Behavioural Researchers on Asians) and cE-Bs (Centre for Environment-Behaviour Studies), Faculty of Architecture, Planning \& Surveying, Universiti Teknologi MARA, Malaysia.

DOI: https://doi.org/10.21834/e-bpj.v5i13.2094 
premises, which may reflect the hotels' sense of inclusive hospitality despite the challenge in carefully preserving the buildings' heritage value.

\subsection{Literature Review}

\subsection{Heritage Boutique Hotel and Its Conservation}

Other than the means of transportation and places of attraction, tourist accommodation is also a crucial part of accessible tourism. In today's social networking era, tourists' place of stay has also become the ultimate travel destination where a unique and aesthetically well-designed hotel has often become the choice for a travelogue and social media posts. This lifestyle leads to an increase in stay at the boutique hotel, a small-scaled hotel that provides specialized services to the guests. Among the many types of boutique hotels across the world, the ones that are housed in the historical premise are most likely to offer a more meaningful experience; hence, they are more appealing to today's' tourists (Abdul Kadir et al., 2019). In Southeast Asia, especially, there is an increasing demand and supply of heritage boutique hotels due to their unique cultural fusion that other places do not have (Henderson, 2011).

Heritage boutique hotel signifies distinctive cultural identity that depicts the character of the culture, people, and history of the place (Abdul Kadir et al., 2019; Chang \& Teo, 2009; Umar \& Said, 2018). Some of the boutique hotel characteristics that become their charms to many local and international tourists include unique architectural and interior style (Henderson, 2013; Khosravi et al., 2012; Lee \& Chhabra, 2015; Mundo-Hernández et al., 2015), and individualization or personalized services (Arifin et al., 2018; Khosravi et al., 2012). Because of the historical value that the original premise of heritage boutique hotel owned, careful conservation process and management need to be conducted during the restoration. The conservation of heritage buildings needs to be done meticulously and systematically to protect their historical originality and cultural value (Harun, 2011; Jason \& Gomathy, 2008; Ujang et al., 2018).

\subsection{The Significance of Accessibility Adaptation in Heritage Boutique Hotel}

Many precedent studies on heritage building have projected the issues of inaccessible built heritage environment (Bragança, Fernandes, Botelho \& Batista, 2006; Cameron, Darcy \& Foggin, 2003; Evcil, 2018; Jamaludin \& Abdul Kadir, 2012; Zahari, Harun, Ahmad, Zawawi, \& Salim, 2016). Concerning that, some studies advise for a better accessibility provision at the heritage site to ensure more accessible tourism (Kose, 2015; Said et al., 2013) and stronger place attachment (Ujang et al., 2018). Besides, having the provisions of inclusivity in tourism may contribute to the socially sustainable heritage assets of a country (Liusman et al., 2013). Therefore, it is significant to explore on attentive methods of accessibility adaptation in heritage boutique hotels to preserve the cultural heritage value that the property holds.

According to ICOMOS New Zealand Charter (2010), "adaptation means the process(es) of modifying a place for a compatible use while retaining its cultural heritage value" (p.9). Accessibility adaptation should be integrated into the conservation process to avoid later alteration that may risk the original building fabric. Besides, providing an accessible environment in a heritage boutique hotel ensures comfortable hotel experience, which may result in positive hotel review and repeating stay. Table 1 lists a set of guidelines for adaptation in heritage building as established by ICOMOS New Zealand Charter (2010).

Table 1. Guidelines for Adaptation in Heritage Building

\begin{tabular}{ll}
\hline No. & Guidelines for Adaptation in Heritage Building \\
\hline 1. & Alterations and additions may be acceptable where they are necessary for a compatible use of the place. \\
2. & Any change should be the minimum necessary, should be substantially reversible, and should have little or \\
no adverse effect on the cultural heritage value of the place.
\end{tabular}

(Source: ICOMOS New Zealand Charter, 2010)

\subsection{Malacca City as the Centre of Multicultural Heritage}

Malacca City is a popular tourist destination in Malaysia for the cultural heritage it owns. The city was recognized as UNESCO World Heritage Site in 2008, denoting a recognition for Malaysian government effort in sustaining and preserving the nation's valuable historical assets (Hanafi, Abdul Razak, Abdul Rashid \& Umar, 2018). Furthermore, according to Bakri, Ibrahim, Sh. Ahmad and Qamaruz Zaman (2015), the UNESCO recognition were awarded due to Malacca City fulfillment of Outstanding Universal Values (OUV), as indicated in Table 2.

Table 2. Malacca City Fulfilment of Outstanding Universal Values (OUV)

\begin{tabular}{ll}
\hline OUV Criterion & Guidelines for Adaptation in Heritage Building \\
\hline Criterion (ii) & $\begin{array}{l}\text { Represent exceptional examples of multi-cultural trading towns in East and Southeast Asia. } \\
\text { Criterion (iii) }\end{array}$ \\
$\begin{array}{l}\text { Bear living testimony to the multi-cultural heritage and tradition of Asia, and European colonial } \\
\text { influences. }\end{array}$ \\
$\begin{array}{l}\text { Reflects a mixture of influences that have created a unique architecture, culture, and } \\
\text { townscape without parallel anywhere in East and South Asia. }\end{array}$ \\
\hline
\end{tabular}

(Source: Bakri et al., 2015) 
The built heritage of Malacca City is valuable as in the tangible as well as intangible forms. The multicultural inheritance of Malacca was a result of "previous inter- and intra- region development (as residential and commercial centers) during the 16th-18th centuries", thus leaving behind numerous built historical remnants (Raja Othman \& Hamzah, 2013, p.579). A recent study of four areas, including Malacca City by Mat Zin, Ismail and Md. Azmi (2018) found that the heritage property market in all the case studies is stable from 2004 to 2017. Besides, a study by Hussain and Ujang (2014) emphasizes the vitality of built heritage value on visitors' perception of Malacca's place identity. Considering Malacca City as one of the Malaysian prominent heritage centres, various studies that take on different aspects of its inheritance are crucial to sustaining the cultural assets for future generations.

\subsection{Methodology}

\subsection{Malacca Case Studies}

As discussed previously, Malacca was chosen as the research location due to its reputation as the UNESCO heritage site, which implies the significance of its tangible and intangible heritage values. Also, because of the high visiting rate of local and international tourists to Malacca, it is noteworthy to scope this accessibility study to the tourist accommodation. The three heritage boutique hotels were selected for their different location, original building types, and cultural heritage that the original buildings signify, as described in Table 3 .

Table 3. Selected Heritage Boutique Hotels for Accessibility Adaptation Case Studies in Malacca

\begin{tabular}{|c|c|c|c|}
\hline Aspects & 1825 GALLERY HOTEL & HOTEL PURI & THE MAJESTIC MALACCA \\
\hline Pear Built & 1825 & 1822 & 1929 \\
\hline Location & $\begin{array}{l}\text { - Jalan Bunga Raya, Malacca } \\
\text { - By Malacca River }\end{array}$ & $\begin{array}{l}\text { - Jalan Tun Tan Cheng Lock, Malacca } \\
\text { - Known as Heeren Street by the Dutch } \\
\text { - It was also nicknamed Millionaires' Row as } \\
\text { most of the Chinese millionaires of the } \\
\text { pioneering period lived on this street. }\end{array}$ & $\begin{array}{l}\text { - Jalan Bunga Raya, Malacca } \\
\text { - Located on the banks of the Malacca River, } \\
\text { which in the past abounded with Chinese } \\
\text { junks and spice-laden vessels from all over } \\
\text { the world. }\end{array}$ \\
\hline $\begin{array}{l}\text { Original Function/ } \\
\text { Building }\end{array}$ & $\begin{array}{l}\text { A flour storehouse that had stockpiled } \\
\text { imported flour from abroad since its } \\
\text { establishment. }\end{array}$ & $\begin{array}{l}\text { Peranakan house which once belonged to } \\
\text { the descendants of an eminent philanthropist } \\
\text { and rubber plantation owner, Tan Kim Seng. } \\
\text { It was the ancestral home of the } \\
\text { descendants of Tan Kim Seng (1805-1864). }\end{array}$ & $\begin{array}{l}\text { Straits Settlement private mansion of a } \\
\text { tycoon named Leong Long Man where } \\
\text { imported Victorian tiles, stained glass } \\
\text { windows, expensive furniture and fittings } \\
\text { were all incorporated into his home. }\end{array}$ \\
\hline $\begin{array}{l}\text { Culture Signified by } \\
\text { the Heritage }\end{array}$ & $\begin{array}{l}\text { It is more than just being a hybrid } \\
\text { architecture influenced by the British and the } \\
\text { Chinese - but on a more profound level, it } \\
\text { represents the spirits of the Chinese } \\
\text { workforce that had contributed significantly } \\
\text { to the trade of Malacca. }\end{array}$ & $\begin{array}{l}\text { Peranakan culture - a mix of Chinese, } \\
\text { Western and local flavours. Malay became } \\
\text { the lingua franca of their offsprings. } \\
\text { However, the babas and Nyonya continued } \\
\text { to practice the customs and traditions of their } \\
\text { Chinese forefathers, while at the same time } \\
\text { absorbed and assimilated some local way of } \\
\text { life especially in the attires of the Nyonya and } \\
\text { in food preparation. }\end{array}$ & $\begin{array}{l}\text { The Kristang heritage arose between the } \\
16 \text { th and } 17 \text { th centuries. Malacca welcomed } \\
\text { weary travelers (i.e., sailors, traders, and } \\
\text { soldiers), many of whom married local native } \\
\text { women. Their descendants marked the } \\
\text { beginning of the Kristang community, mainly } \\
\text { of Portuguese descent though many also } \\
\text { have a strong Dutch heritage, as well as } \\
\text { some British, Chinese, and Indian ancestry. }\end{array}$ \\
\hline $\begin{array}{l}\text { Built Heritage } \\
\text { Conserved }\end{array}$ & $\begin{array}{l}\text { - The wooden floor and ceiling of the hotel } \\
\text { are the actual timbers of the historical } \\
\text { building, well-preserved over time since the } \\
\text { 1890s. } \\
\text { - The windows of the hotel: Outshine the } \\
\text { unique design of the building. } \\
\text { - The walls: Admired for its unique motives } \\
\text { based on Chinese-influenced architecture, } \\
\text { its walls are distinct from those of modern } \\
\text { buildings in terms of structural strength, } \\
\text { masonry work and others, thus denoting the } \\
\text { significance of ancient wisdom. }\end{array}$ & $\begin{array}{l}\text { - The building from the front to the inner court } \\
\text { or the Ancestral Hall was carefully reinstated } \\
\text { preserving the original structures together } \\
\text { with its carved doorways, windows, partitions } \\
\text { and interestingly sculptured airwell. } \\
\text { - Chinese couplets of good fortune, health, } \\
\text { and happiness adorning doors, windows and } \\
\text { entrances just as the Chinese residences in } \\
\text { China, were meticulously restored. } \\
\text { - The mosaic and wall tiles were imported } \\
\text { from } 19 \text { th century England, hence the } \\
\text { similarity to those in the old houses in } \\
\text { England of the same period. }\end{array}$ & $\begin{array}{l}\text { - The heart of the hotel is a restored } 1920 \mathrm{~s} \\
\text { Straits Settlement mansion complete with its } \\
\text { original porcelain tile flooring and teakwood } \\
\text { fittings. } \\
\text { - The hotel had taken a turn for the worse in } \\
2000 \text {, operating as a guesthouse with a run- } \\
\text { down air. Acknowledging the need to } \\
\text { preserve an integral part of Malacca's rich } \\
\text { heritage, YTL Hotels stepped in and the } \\
\text { property acquisition was finalised in } 2006 \text {. } \\
\text { - The historic building was fully restored and } \\
\text { reopened as The Majestic Malacca in } \\
\text { January } 2008 \text { with much fanfare. }\end{array}$ \\
\hline
\end{tabular}

(Source: 1825 Gallery Hotel, 2020; Hotel Puri Melaka, 2020; The Majestic Malacca, 2020)

\subsection{Research Method}

The observation was employed as the primary method of this research, which includes site observation and photo documentation at the selected case studies. The scope of observation is within the hotels' common area where the accessibility provisions for all hotel guests are located. The accessibility features that were assessed in the observation are parking space, ramp, corridors and walkways, entrance, doors and doorways, persons with disability (PWD) restroom, stairs and stairways, elevator, overall signage, and emergency means of escape. The site observation examines the availability of accessibility provisions, their attributes based on Malaysian Standard for Universal Design and Accessibility in the Built Environment, and the hotels' conserved heritage features. Data were analyzed qualitatively with the help of photo documentation, which was also done during the observation.

\subsection{Limitation}

The methodology is based on observation of the researcher only, and not from other perspectives such as from hotel guests' perception. A further study that considers the users' point of view may strengthen the validity of the study. Furthermore, the research covers only three case studies of heritage boutique hotels in Malacca; therefore, generalization to the majority of heritage boutique hotels in Malacca 
should be avoided. Researches on other heritage boutique hotels can be done in the future to investigate the subject matter more expansively.

\subsection{Findings and Discussion}

Table 4 encapsulates the provisions of accessibility adaptation in the design of heritage boutique hotels based on observation at the three case studies.

Table 4. The Provisions of Accessibility Adaptation at the Case Studies

\begin{tabular}{|c|c|c|c|}
\hline Accessibility Provision & 1825 GALLERY HOTEL & HOTEL PURI & THE MAJESTIC MALACCA \\
\hline 1) Parking Space & $\begin{array}{l}\text { There are parking spaces in front of the } \\
\text { hotel and designated parking areas for } \\
\text { hotel guests (provided with a surveillance } \\
\text { camera). }\end{array}$ & $\begin{array}{l}\text { There is designated parking area for hotel } \\
\text { guests within a } 2 \text { minutes walking distance } \\
\text { (provided with surveillance camera). }\end{array}$ & $\begin{array}{l}\text { There is ample space for drop-off in front of } \\
\text { the hotel and a designated parking area for } \\
\text { hotel guests located next to the main hotel } \\
\text { building (provided with a security guard). }\end{array}$ \\
\hline 2) Ramp & $\begin{array}{l}\text { A ramp is provided from parking space to } \\
\text { the hotel corridor. }\end{array}$ & $\begin{array}{l}\text { Interior ramps provided where there is a } \\
\text { level change between different spaces on } \\
\text { the hotel ground floor. }\end{array}$ & $\begin{array}{l}\text { A ramp is provided at the hotel front } \\
\text { corridor, and there is a portable ramp } \\
\text { installed that connects the main hotel } \\
\text { building with the path to hotel rooms. }\end{array}$ \\
\hline $\begin{array}{l}\text { 3) Corridor and } \\
\text { Walkways }\end{array}$ & $\begin{array}{l}\text { Appropriate size for approach and use at } \\
\text { the hotel front corridor and hotel interior. }\end{array}$ & $\begin{array}{l}\text { The corridors between shophouses at the } \\
\text { area were originally blocked for tenants' } \\
\text { privacy during its old-time, thus, they are } \\
\text { retained for heritage conservation. }\end{array}$ & $\begin{array}{l}\text { Appropriate size for approach and use at } \\
\text { the hotel front corridor and hotel interior. }\end{array}$ \\
\hline 4) Entrance & Appropriate size for approach and use. & Appropriate size for approach and use. & Appropriate size for approach and use. \\
\hline $\begin{array}{l}\text { D) Doors and } \\
\text { Doorways }\end{array}$ & Appropriate size for approach and use. & Appropriate size for approach and use. & Appropriate size for approach and use. \\
\hline 6) Elevator & $\begin{array}{l}\text { Elevators with the appropriate size, space, } \\
\text { and fittings adapted into the hotel design. }\end{array}$ & $\begin{array}{l}\text { Elevators with the appropriate size, space, } \\
\text { and fittings adapted into the hotel design, } \\
\text { at one of the airwell. }\end{array}$ & $\begin{array}{l}\text { PWD lift is provided between the path from } \\
\text { the main hotel building to the additional } \\
\text { building where hotel rooms are located. } \\
\text { Elevators to the hotel rooms are } \\
\text { accessible. }\end{array}$ \\
\hline 7) Stairs and stairways & $\begin{array}{l}\text { Appropriate design and size of the } \\
\text { staircase run from the main floor to the } \\
\text { upper floors. }\end{array}$ & $\begin{array}{l}\text { Original wooden staircases of the } \\
\text { shophouse are retained for heritage } \\
\text { conservation. }\end{array}$ & $\begin{array}{l}\text { At the main hotel building, the original } \\
\text { wooden staircases of the mansion are } \\
\text { retained for heritage conservation. }\end{array}$ \\
\hline 8) PWD Restroom & $\begin{array}{l}\text { PWD restroom with appropriate design and } \\
\text { configuration is provided at the hotel's } \\
\text { common area. }\end{array}$ & $\begin{array}{l}\text { PWD restroom with appropriate design and } \\
\text { configuration is provided at the hotel's } \\
\text { common area. }\end{array}$ & $\begin{array}{l}\text { PWD restroom with appropriate design and } \\
\text { configuration is provided at the hotel's } \\
\text { common area. }\end{array}$ \\
\hline 9) Signage & $\begin{array}{l}\text { Visible overall signage in the hotel interior. } \\
\text { Hotel map is provided at each level for } \\
\text { guests' sense of wayfinding. }\end{array}$ & $\begin{array}{l}\text { Visible overall signage in the hotel interior. } \\
\text { Hotel map is provided at each level for } \\
\text { guests' sense of wayfinding. }\end{array}$ & $\begin{array}{l}\text { Visible overall signage in the hotel interior. } \\
\text { Hotel map is provided at each level for } \\
\text { guests' sense of wayfinding. }\end{array}$ \\
\hline $\begin{array}{l}\text { 10) Emergency Means } \\
\text { of Escape }\end{array}$ & $\begin{array}{l}\text { Visible exit signage and hotel map are } \\
\text { provided at each level for fire/ emergency } \\
\text { escape. } \\
\text { Fire/ emergency exit is cleverly adapted at } \\
\text { the left side of the hotel building. }\end{array}$ & $\begin{array}{l}\text { Visible exit signage and hotel map are } \\
\text { provided at each level for fire/ emergency } \\
\text { escape. }\end{array}$ & $\begin{array}{l}\text { Visible exit signage and hotel map are } \\
\text { provided at each level for fire/ emergency } \\
\text { escape. }\end{array}$ \\
\hline
\end{tabular}

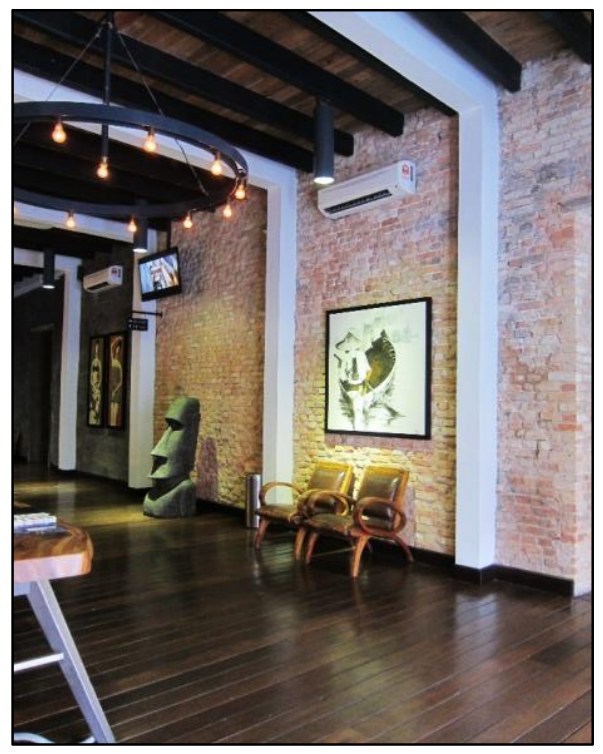

(a)

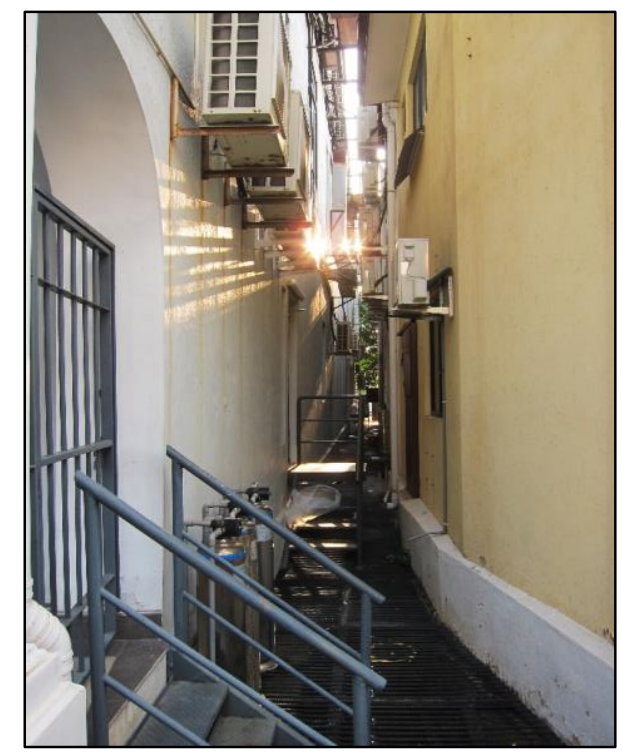

(b)

Fig. 1. (a) Open layout of 1825 Gallery hotel interior; (b) Grill platform installed at the emergency exit. 
In general, the provisions of accessibility adaptation in the design of assessed heritage boutique hotels are sufficient and appropriate to the Malaysian Standard for Universal Design and Accessibility in the Built Environment. For the first case study, the open layout of the original flour storehouse building of 1825 Gallery Hotel may have allowed for a more flexible accessibility adaptation. For instance, the hotel was designed with appropriate size for approach and use of interior corridor and walkways, doors and doorways, stairs and stairways, elevator, and emergency mean of escape. The highlight of 1825 Gallery Hotel accessibility adaptation is the clever provision of fire/ emergency exit at the left side of the hotel, where grill platforms were installed on top of open drainage to support the emergency exit staircases, as shown in Fig.1(b).

The second case study, Hotel Puri, also provides good accessibility adaptation throughout the hotel while successfully preserved its Peranakan cultural heritage with its abundant display of antiques and original building fabrications. The hotel elevator with fully accessible fittings (i.e., appropriate rail and Braille buttons design and height for PWD) is brilliantly adapted at one of the building's airwells. Besides, the elevator design matches with the interior scheme and style, as if the accessible facility was already a part of the building heritage, as depicted in Fig. 2(b).

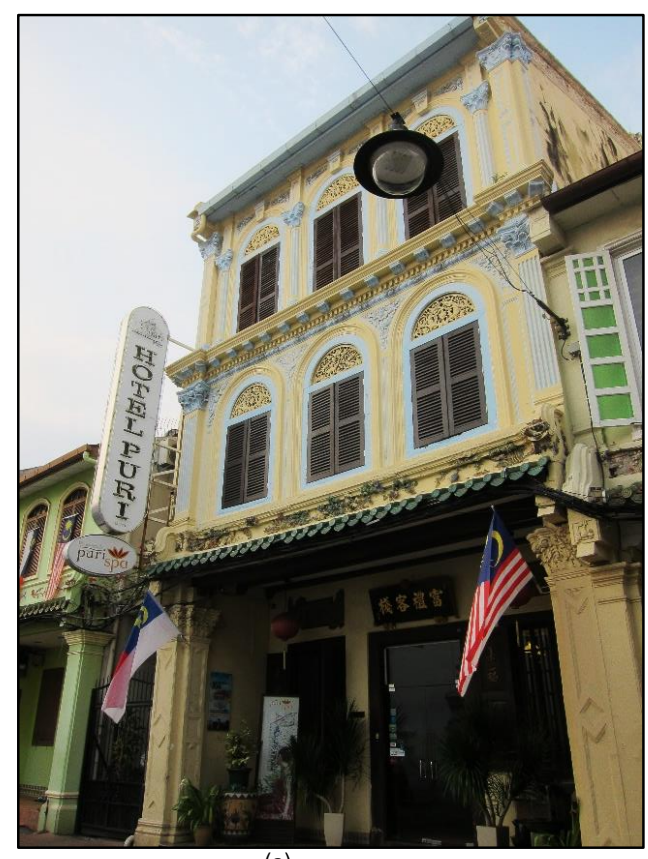

(a)

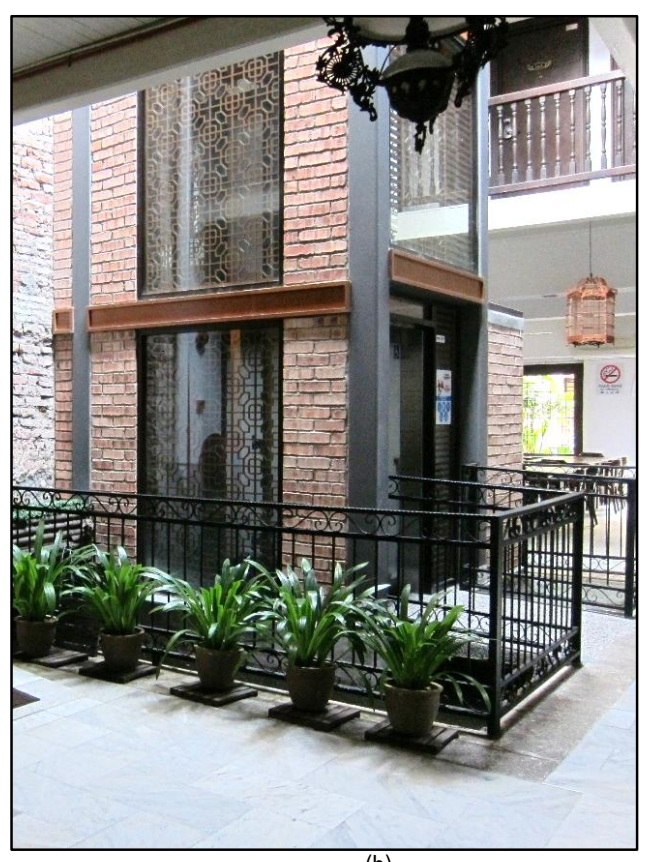

(b)

Fig. 2. (a) Hotel Puri beautifully conserved façade; (b) Elevator adapted at Hotel Puri airwell.

The Majestic Malacca, the third case study, also shows good accessibility adaptation in their hotel design, along with the beautifully restored Straits Settlement mansion. Situated on their private land, the hotel has an impressive first impression with not only the elegant building façade but also the accessible and ample hotel front area when the guests arrive. The small yet crucial accessibility details such as the portable ramp, and the PWD lift installed between the path from the main hotel building to the additional structure, show the hotel's extra attention to the needs of all hotel guests.

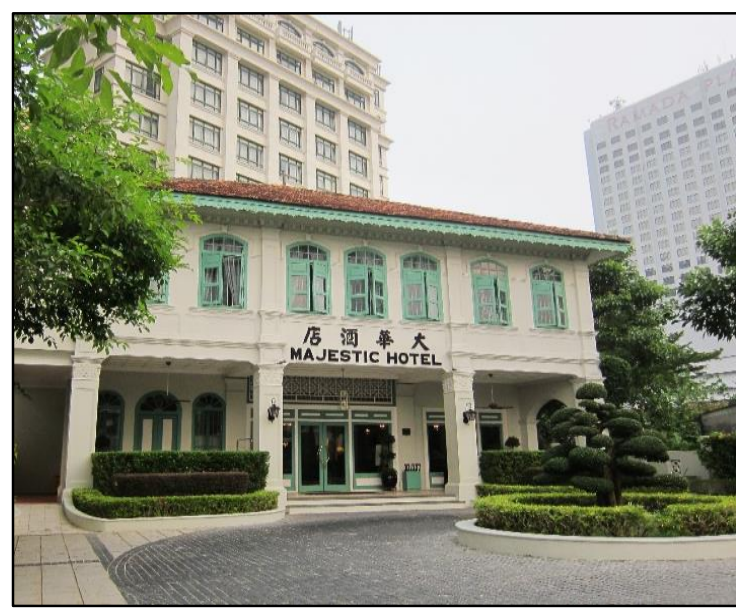

(a)

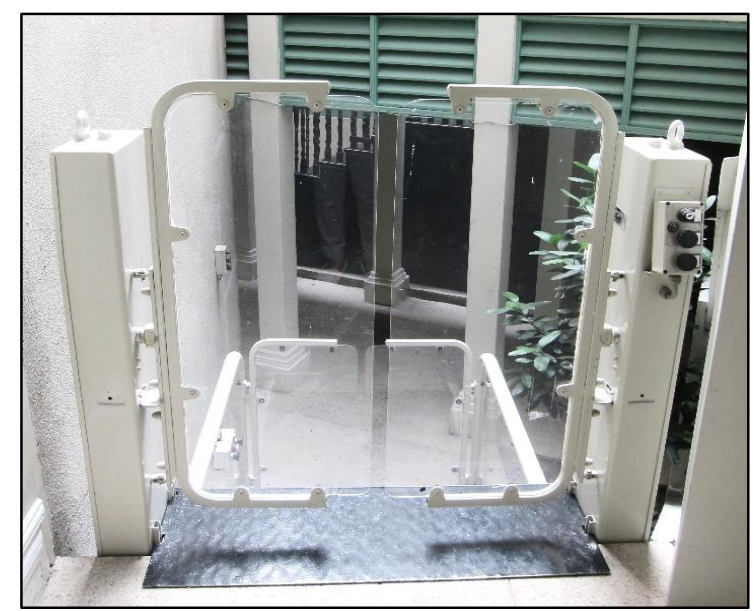

(b)

Fig. 3. (a) The Majestic Malacca elegant impression and accessible front area; (b) PWD lift adapted at The Majestic Malacca. 


\subsection{Conclusion and Recommendation}

In conclusion, all three case studies were designed with users' accessibility in mind despite the buildings' heritage value that they need to preserve. Accessibility facilities that are provided at the case studies include appropriate size and space for approach and use of the parking space, ramp, corridors and walkways, entrance, doors and doorways, elevator, PWD restroom, and overall signage. Moreover, even though the hotels are housed in historic buildings, their layouts are easy to comprehend regardless of guests' experience coming to the hotels. These positive traits of accessibility adaptation in heritage boutique hotels suggest a better development of the Malaysian tourism industry towards accessible tourism, which may attract more extensive ranges of tourist.

This research hopes to have successfully gathered information on the current accessibility adaptation in several renowned heritage boutique hotels in Malacca City, as an additional source to the heritage conservation development in Malaysia mainly. The methods of accessibility adaptation by the three case studies can be a good reference to other heritage buildings that wish to provide better accessibility for their users or visitors. Future researches can be done on accessibility adaptation in other heritage boutique hotels and different heritage cities such as Ipoh and George Town City.

\section{Acknowledgements}

The authors would like to acknowledge the Institute of Research Management \& Innovation (IRMI), Universiti Teknologi MARA (UiTM) for funding this research through the Lestari Research Grant: 600-IRMI 5/3/LESTARI (050/2018).

\section{References}

1825 Gallery Hotel (2020). 1825 Gallery Hotel History. Retrieved from http://1825galleryhotel.com/about-us/hotel-history/

Abdul Kadir, S., Jamaludin, M. \& Awang, A.R. (2019). Accessibility Adaptation in Heritage Boutique Hotels: A review on literature, Environment-Behaviour Proceedings Journal, 4(10), 103-108.

Arifin A.S., Ahmad A., \& Jamal S.A. (2018). Factors of Guest Experiential Value of Boutique Hotels in the City of Kuala Lumpur, Journal of Tourism and Hospitality, 7(2), 342.

Bakri, A.F., Ibrahim, N., Sh Ahmad, S. \& Qamaruz Zaman, N. (2015). Valuing Built Cultural Heritage in a Malaysian Urban Context, Procedia - Social and Behavioral Sciences, 170, 381-389.

Bragança, L., Fernandes, C., Botelho, H. \& Batista, I. (2006). Accessibility adaptation of a building in a historical city centre, POLIS/BAS Conference, 16 \& 17 November 2006, p.1-7.

Cameron, B., Darcy, S., \& Foggin, E. (2003). Barrier-free tourism for people with disabilities in the Asian and Pacific region (ST/ESCAP/2316). New York, NY: United Nations.

Chang, T.C. and Teo, P. (2009). The Shophouse Hotel: Vernacular Heritage in a Creative City. Urban Studies, 46(20), 341-367.

Evcil, A.N. (2018). Barriers and preferences to leisure activities for wheelchair users in historic places, Tourism Geographies, 20(4), 698-715.

Hanafi, M.H., Abdul Razak, A., Abdul Rashid, Z.Z. \& Umar, M.U. (2018). Essential Entities towards Developing an Adaptive Reuse Model for Organization Management in Conservation of Heritage Buildings in Malaysia, Environment-Behaviour Proceedings Journal, 3(7), 265-276.

Harun, S.N. (2011). Heritage Building Conservation in Malaysia: Experience and Challenges. Procedia Engineering, 20, 41 - 53.

Henderson, J.C. (2011). Hip Heritage: The boutique hotel business in Singapore. Tourism and Hospitality Research, 11(3), 217-223.

Henderson, J.C. (2013). Selling the Past: Heritage hotels. Research Note, 61(4), 451-454.

Hotel Puri Melaka (2020). About Hotel Puri. Retrieved from http://hotelpuri.com/about_us.html

Hussain, K.A.M. \& Ujang, N. (2014). Visitors' Identification of Landmarks in the Historic District of Banda Hilir, Melaka, Malaysia, Procedia - Social and Behavioral Sciences, 153, 689-699.

ICOMOS New Zealand Charter (2010). ICOMOS New Zealand Charter for the Conservation of Places of Cultural Heritage Value. Retrieved from https://www.icomos.org/charters/ICOMOS_NZ_Charter_2010_FINAL_11_Oct_2010.pdf

Jamaludin, M. and Abdul Kadir, S. (2012). Accessibility in Buildings of Tourist Attraction: A case studies comparison. Procedia - Social and Behavioral Sciences, 35, 97104.

Jason, G.J. and Gomathy, R. (2008). New Foreign Invasion of Melaka, News Straits Times, 15 July 2008.

Kose, S. (2015). Tourism for All: How can universal/inclusive design accommodate senior travelers? Journal of Universal Design in Built Environment, $1(1), 33$ - 47.

Lee, W. \& Chhabra, D. (2015). Heritage Hotels and Historic Lodging: perspectives on experiential marketing and sustainable culture. Journal of Heritage Tourism, 10(2), 103-110. 
Liusman, E., Ho, D.C.W. \& Ge, J.X. (2013). Indicators for heritage buildings sustainability. Proceedings for CESB13 - Central Europe towards Sustainable Building 2013 $689-692$.

Mat Zin, N., Ismail, S. \& Md. Azmi, F.A. (2018). Ascertaining the Economic Sustainability of Heritage Property Market based on Sales Transaction Analysis, EnvironmentBehaviour Proceedings Journal, 3(7), 247-254.

Mohd Azizi, N.Z., Abdul Razak, A., Mohd Din, M.A. \& Mat Nasir, N. (2015). Recurring Issues in Historic Building Conservation. Procedia - Social and Behavioral Sciences $222,587-595$

Mundo-Hernández, J., Valerdi-Nochebuena, M.C. \& Sosa-Oliver, J. (2015). Post-occupancy evaluation of a restored industrial building: A contemporary art and design gallery in Mexico. Frontiers of Architectural Research, 4, 330-340.

National Institute of Public Administration (2015). Eleventh Malaysia Plan. Retrieved from https://www.intanbk.intan.my/iportal/en/rmk11

Raja Othman, R.N. \& Hamzah, A. (2013). Interdependency of Cultural Heritage Assets in the Old Quarter, Melaka Heritage City, Procedia - Social and Behavioral Sciences, 105, 577-588.

Said, S.Y., Aksah, H. \& Ismail, E.D. (2013). Heritage Conservation and Regeneration of Historic Areas in Malaysia. Procedia - Social and Behavioral Sciences, 105, 418428.

The Majestic Malacca (2020). Our Story. Retrieved from https://www.majesticmalacca.com/pages/our-story.html

Ujang, N., Moulay, A. \& Zakaria, J. (2018). Visitors' Attachment to Historic Tourism Places in Kuala Lumpur City Centre towards Sustainable Urban Regeneration. 4th AQoL2018/stanbul, Turkey, 03-06 Nov 2018 / E-BPJ, 3(9), 165-172.

Umar, S.B. \& Said, I. (2018). A Review of Decision-making Models in Developed Countries towards Enhancing the Quality of Built Heritage Assets in Developing Countries. 6th AicQoL2018Perhentianlsland, 03-04 March 2018/E-BPJ, 3(7), 237-246.

Zahari, N.F., Harun, S.F., Ahmad, N.A., Zawawi, Z.A. and Salim, N.A.A. (2016). Comparative Analysis of Disabled Accessibility Needs of Heritage Building in Perak. MATEC Web Conf. The 4th International Building Control Conference 2016 (IBCC 2016), 66, 1-5. 